Al-Khwarizmi: Jurnal Pendidikan Matematika dan Ilmu Pengetahuan Alam

Oktober-2020, Vol.8, No.2, hal.173-182

$\operatorname{ISSN}(P): 2337-7666 ; \operatorname{ISSN}(E): 2541-6499$

https://ejournal.iainpalopo.ac.id/index.php/al-khwarizmi

DOI:http://dx.doi.org/10.24256/ipmipa.v8i2.1542

\title{
Pengembangan Lembar Kerja Peserta Didik Berbasis Masalah dalam Meningkatkan Pemahaman Konsep Aljabar
}

\author{
${ }^{1}$ Basri, ${ }^{2}$ Thamrin Tayeb, ${ }^{3}$ Andi Ika Prasasti Abrar, ${ }^{4}$ Fitriani Nur, \\ ${ }^{5}$ Andi Dian Angriani \\ Jurusan Pendidikan Matematika, Fakultas Tarbiyah dan Keguruan, UIN Alauddin Makassar \\ Jl. H.M.Yasin Limppo No.36 Romangpolong Kec. Sombaopu, Sulawesi Selatan, 92113 \\ Email: basrhy994@gmail.com
}

Article History:

Received: 30-08-YYYY; Received in Revised: 17-10-2020; Accepted: 26-10-2020

\begin{abstract}
Lembar Kerja Peserta Didik (LPKD) can help students understand the concept of material, both theoretically and in real events that often occur in everyday life. This study tries to determine the development process and quality of LKPD to improve students' understanding the concepts of algebra. The development research used refers to the Plomps model, which includes 4 phases: (a) the initial investigation, (b) the design, (c) the realization, and (d) the test, evaluation, and revision. The product assessment instrument used was the LKPD validation sheet, the LKPD observance sheet, student and teacher response questionnaires, student and teacher activity observation sheets, and tests of students' ability to understand mathematical concepts. The LKPD that was designed and tested on grade VII students at one of the schools in Soppeng had met the criteria of being valid, effective, and practical.
\end{abstract}

Keywords: Teaching Material; LKPD Based on Problem; Understanding the Concepts of Algebra.

\begin{abstract}
Abstrak
Lembar Kerja Peserta Didik (LPKD) berbasis masalah dapat membantu peserta didik memahami konsep materi, baik secara teori maupun dalam peristiwa nyata yang sering terjadi dalam kehidupan sehari-hari. Penelitian ini mencoba mengetahui proses pengembangan dan kualitas LKPD matematika berbasis masalah untuk meningkatkan pemahaman konsep aljabar peserta didik. Penelitian pengembangan yang digunakan mengacu pada model pengembangan Plomp, yang meliputi 4 fase, yaitu: (a) fase investigasi awal, (b) fase desain, (c) fase realisasi, dan (d) fase tes, evaluasi, dan revisi. Instrumen penilaian produk yang digunakan adalah lembar validasi LKPD, lembar pengamatan keterlaksaan LKPD, angket respon peserta didik dan guru, lembar pengamatan aktivitas peserta didik dan guru, dan tes kemampuan pemahaman konsep matematika peserta didik. LKPD yang didesain dan diujicobakan kepada siswa kelas VII di salah satu sekolah di Soppeng telah memenuhi kriteria valid, efektif dan praktis.
\end{abstract}

Kata Kunci: Bahan Ajar, LKPD Berbasis Masalah; Pemahaman Konsep Aljabar. 


\section{Pendahuluan}

Pendidikan memberikan pengaruh dalam pembangunan bangsa yang cerdas. Kontribusi bangsa terhadap pendidikan menunjukkan bangsa tersebut maju. Kualitas pendidikan akan menentukan kualitas sumber daya manusia di suatu Negara. ${ }^{1}$ Tujuan pendidikan di sekolah adalah keberhasilan proses pembelajaran yang mempengaruhi hasil belajar peserta didik. Guru dan peserta didik adalah komponen-komponen yang diperlukan dalam proses pembelajaran. Dalam mencapai keberhasilan dalam proses pendidikan, komponen-komponen tersebut memiliki peran penting. Guru sebagai pendidik membimbing peserta didik dan memanfaatkan media pembelajaran yang tersedia secara optimal. Salah satunya penggunaan sumber pembelajaran dalam sekolah seperti LKPD. Selain itu, guru juga perlu menggunakan model pembelajaran yang tepat dalam proses pendidikan. Penggunaan model pembelajaran penting dalam mengatasi kebosanan peserta didik dan konsep yang kurang dipahami, yang dapat menyebabkan motivasi peserta didik menurun dalam menggunakan LKPD.

Salah satu pelajaran yang penting untuk diperhatikan dalam penggunaan model pembelajaran agar tidak membosankan adalah matematika. Matematika adalah ilmu pengetahuan yang dapat memajukan daya pikir manusia. Dalam menguasai dan menciptakan teknologi di masa depan diperlukan penguasaan matematika sejak dini, terutama bagi peserta didik yang akan menjadi penerus bangsa ${ }^{2}$. Dengan adanya pelajaran matematika akan membekali peserta didik dengan kemampuan berpikir logis, analitis, sistematis, kritis, dan kreatif serta kemampuan bekerjasama. Pembelajaran matematika yang baik akan menunjang peningkatan kemampuan matematika peserta didik, sebaliknya pembelajaran dengan menekankan pada hafalan menyebabkan peluang peserta didik memiliki kemampuan matematis tinggi menjadi kecil. Oleh karena itu, dalam menyampaikan berbagai konsep yang diajarkan di sekolah diperlukan model pembelajaran yang tepat. ${ }^{3}$

Berdasarkan hasil wawancara dengan guru matematika diperoleh bahwa hasil belajar peserta didik kelas VII pada ranah kognitif masih sangat rendah, yakni, terdapat $70 \%$ peserta didik (57 orang dari 81 peserta didik) kelas VII yang hasil belajarnya belum mencapai KKM, yaitu nilai 75. Guru matematika tersebut mengatakan bahwa dalam proses pembelajaran peserta

1 Farah Nidyasafitri, "Pengembangan LKS Berbasis PBL (Problem Based Learning) Pada Pokok Bahasan Momentum Dan Impuls Fisika SMA Kelas XI" (Universitas Negeri yogyakarta, 2017).

2 Sumaryanta, Bahan Perkuliahan Telaah Kurikulum Pendidikan Matematika (Yogyakarta: UIN Sunan Kalijaga, 2009).

3 Novi Pusparini, "Efektivitas Model Pembelajaran Kooperatif Tipe TGT Terhadap Prestasi Belajar Matematika Peserta didik SMP Kelas VIII” (UIN Sunan Kalijaga, 2011). 
didik tampak kesulitan dalam memahami materi matematika ${ }^{4}$. Kemampuan penyelesaian masalah peserta didik terhadap permasalahan nyata masih kurang. Salah satu penyebabnya adalah soal-soal pemecahan masalah yang diberikan guru kepada peserta didik kurang dibarengi dengan langkahlangkah pengerjaan, sehingga peserta didik kurang memahami maksud dari soal tersebut. Selain itu, salah satu faktor penyebabnya yaitu, guru masih mengandalkan buku paket dari pemerintah padahal salah satu kelemahan buku paket pemerintah menurut Depdiknas dalam Rosliana (2019) ${ }^{5}$ yaitu jika dilihat dari strukturnya adalah tidak adanya komponen petunjuk belajar, informasi pendukung dan langkah kerja penyelesaian soal sehingga dalam penggunaannya, pemakaian buku paket hanya memungkinkan komunikasi satu arah yang berakibat pada kurangnya kesempatan peserta didik untuk mengembangkan pola pikir termasuk kreativitas berpikirnya dan kurang mendukung peserta didik dalam membangun pengetahuannya sendiri sehingga berakibat pada kemampuan pemahaman konsep yang kurang terasah dengan baik.

Dalam mengatasi masalah tersebut, upaya yang dilakukan adalah dengan menciptakan pembelajaran yang kreatif. Salah satunya adalah mengembangkan Lembar Kerja Peserta Didik (LKPD). Penggunaan LKPD dapat menunjang keberhasilan proses belajar mengajar6 ${ }^{6}$ LKPD berperan dalam peningkatan pemahaman melalui penyajian yang menarik ${ }^{7}$. Penyajian LKPD yang baik akan mempengaruhi respons peserta didik dalam mengerjakan LKPD tersebut. LKPD juga akan membuat peserta didik aktif dalam proses pembelajaran ${ }^{8}$. Hal ini sejalan dengan pendapat Trnova dan Trna (2014) yang menyatakan bahwa LKS akan menciptakan suasana belajar yang berpusat pada peserta didik dan mendorong peserta didik berpikir kreatif 9 .

4 Selasa, 12 Februari 2019.

5 Rosliana, Ina, "Pengembangan LKPD Matematika dengan Model Learning Cycle Berbantuan Mind Mapping”, Jurnal Pengembangan Pembelajaran Matematika (JPPM) 1, no. 1 (2019).

${ }^{6}$ Qomario and Putri Agung, "Pengembangan Lembar Kerja Peserta didik (LKS) IPA Berbasis ICT Sebagai Media Pembelajaran," Jurnal Pendidikan Dan Pembelajaran Dasar 5, no. 2 (2018): 239-246.

7 Safriadi, "Pengembangan Lembar Kerja Peserta didik Berbasis Think-Thalk-Write Pada Mata Pelajaran Matematika Kelas XI SMA Negeri 11 Makassar" (UIN Alauddin Makassar, 2015).

${ }^{8}$ Juniar Afrida, Adlim, and A. Halim, “Pengembangan Lembar Kerja Peserta didik (LKS) Berbasis Inkuiri Terbimbing Untuk Meningkatkan Kemampuan Keterampilan Proses Sains Dan Minat Peserta didik Pada Pembelajaran Fluida Statis Di SMA Negeri 11 Banda Aceh," Jurnal Pendidikan Sains Indonesia 3, no. 1 (2015): 93-106.

9 Eva Trnova and Josef Trna, "Implementation of Creativity in Science Teacher Training," International Journal on New Trends in Education and Their Implications 5, no. 3 (2014): 54-63. 
Salah satu pembelajaran inovatif yang dapat memberikan kondisi belajar aktif dan kreatif kepada siswa adalah pembelajaran berbasis masalah atau Problem Based Learning (PBL) ${ }^{10}$. Sehingga LKPD yang cocok dengan keadaan peserta didik kelas VII di salah satu SMP Negeri di Kabupaten Soppeng adalah LKPD dengan menggunakan model pembelajaran berbasis masalah atau Problem Based Learning (PBL). Model pembelajaran berbasis masalah memberikan kesempatan kepada peserta didik memahami masalah yang berkaitan dengan kehidupan sehari-hari peserta didik 11 dan juga melibatkan peserta didik secara aktif agar tidak merasa bosan dalam proses pembelajaran. ${ }^{12}$

LKPD yang diberikan kepada peserta didik berfungsi untuk melakukan pengamatan, sehingga peserta didik terbantu memahami konsep terkait matematika. Hal ini sejalan dengan penelitian Nidyasafitri, Serevina dan Rustana (2017) ${ }^{13}$ yang mengatakan LPKD berbasis masalah dapat membantu peserta didik memahami konsep materi, baik secara teori maupun dalam peristiwa nyata yang sering terjadi dalam kehidupan sehari-hari. Demikian juga penelitian yang dilakukan oleh Nurhayati, Widodo, dan Soesilowati; serta Savery menerangkan bahwa dengan adanya permasalahan yang diberikan kepada peserta didik, dapat meningkatkan motivasi peserta didik dalam proses pembelajaran ${ }^{1415}$. PBL juga menuntun peserta didik untuk lebih mandiri dan percaya diri ${ }^{16}$, memperoleh pengetahuan dan konsep dasar dari suatu materi ${ }^{17}$, sehingga peserta didik dapat berlatih menyelesaikan masalah yang dihadapinya ${ }^{18}$. Oleh karena itu, artikel ini mencoba mengkaji proses

10 Risfalidah, Rosidin, Undang dan Sutiarso, "Pengembangan LKPd Berbasis Problem Based Learning ditinjau dari disposisi dan Kemampuan Komunikasi Matematis", JPPM 12, No. 2 (2019).

${ }^{11}$ Arends, Richard I., Learning to Teach, Seventh Ed (New York: McGraw-Hill, 2008).

12 Heri Setyanto, Sudarmin, and Novi Ratna Dewi, "Pengembangan LKS IPA Berbasis Problem Based Learning Pada Tema Pencemaran Lingkungan Guna Menumbuhkan Kemandirian Peserta didik," UNNES Science Education Journal 4, no. 3 (2015): 990-997.

13 Farah Nidyasafitri, Vina Serevina, and Cecep E. Rustana, "Pengembangan LKS Berbasis PBL (Problem Based Learning) Pada Pokok Bahasan Momentum Dan Impuls Fisika SMA Kelas XI," Jurnal Wahana Pendidikan Fisika, 2017, 51-57.

${ }^{14}$ Fitri Nurhayati, Joko Widodo, and Etty Soesilowati, "Pengembangan LKS Berbasis Problem Based Learning (PBL) Pokok Bahasan Tahap Pencatatan Akuntansi Perusahaan Jasa," JEE: Journal of Economic Education 1 (2015): 14-19.

15 Savery, "Over of Problem-Based Learning: Definitions and Distinctions," Interdiciplinari Journal1, no. 1 (2006): 9-20.

16 Sudi Dul Aji and Muhammad Nur Hudha, "Karya Ilmiah Peserta didik SMP Dan SMA Melalui Authentuc Problem Based Learning (APBL)," Jurnal Inspirasi Pendidikan 6, no. 1 (2016): 835-841.

17 Nurhadi, Pembelajaran Kontekstual Dan Penerapannya Dalam KBK (Malang: UM Press, 2014).

18 A Zulfikar, “Analyzing Educational Univeristy Students' Conceptions Through Smartphone-Based PDEODE Tasks on Magnetic Field in Sveral Mediums," in In AIP Conference Proceedings (AIP Publishing, 2017). 
pengembangan dan kualitas LKPD matematika berbasis masalah untuk meningkatkan pemahaman konsep aljabar peserta didik.

\section{Metode}

Jenis penelitian yang digunakan adalah Research \& Development (R\&D) dengan mengacu pada model pengembangan Plomp, yang meliputi 4 fase, yaitu: (a) fase investigasi awal (preliminary investigation), (b) fase desain (design), (c) fase realisasi (realization), dan (d) fase tes, evaluasi, dan revisi (test, evaluation, and revision). ${ }^{19}$ Subjek uji coba dalam penelitian ini adalah peserta didik di salah satu SMP Negeri di Kabupaten Soppeng yang berjumlah 27 orang. Teknik dan instrumen penilaian produk yang digunakan terdiri dari lembar validasi LKPD, lembar pengamatan keterlaksaan LKPD, angket respon peserta didik dan guru, lembar pengamatan aktivitas peserta didik dan guru, dan tes kemampuan pemahaman konsep matematika peserta didik. Dalam penelitian ini, data dikumpulkan dengan menggunakan lembar validasi, observasi, angket, dan tes. Analisis data yang digunakan dalam penelitian ini, yaitu analisis kevalidan, analisis kepraktisan, dan analisis keefektifan.

\section{Hasil dan Diskusi}

Hasil validasi LKPD berdasarkan kualitas isi, kualitas bahasa, kualitas penyajian, dan kualitas kegrafikaan berada pada kategori valid. Adapun hasil validasi dari validator ahli mengenai instrumen penelitian dan RPP juga berada pada kategori valid. Setelah kegiatan uji coba, selanjutnya tahap evaluasi, yakni kepraktisan dan keefektifan LKPD yang telah dikembangkan. Untuk mengetahui data kepraktisan digunakan lembar pengamatan keterlaksaan LKPD, angket respon peserta didik dan guru, sedangkan untuk mengetahui data keefektifan digunkan lembar pengamatan aktivitas peserta didik dan guru, dan tes hasil belajar matematika.

Hasil analisis pengamatan keterlaksanaan LKPD dari semua aspek (langkah-langkah model PBL, interaksi sosial, dan prinsip reaksi) mempunyai rata-rata 0,98 , yakni terlaksana sebagian. Sementara, hasil angket respon peserta didik dan guru berturut-turut dari aspek (tampilan, penyajian isi, dan manfaat) yaitu 83,06 dan 75,83 dengan kategori respon positif.

Hasil analisis aktivitas peserta didik selama tiga kali pertemuan mempunyai rata-rata pesrsentase sebesar 61,97\% dengan kategori baik. Demikian juga hasil analisis kemampuan guru mengelola pembelajaran mempunyai rata-rata seluruh aspek 4,14 dengan kategori baik.

${ }^{19}$ Rochmad, "Desain Model Pengembangan Perangkat Pembelajaran Matematika," Jurnal Kreano 3, no. 1 (2012) 
Tabel 1. Hasil Pretest Kemampuan Pemahaman Konsep Aljabar

\begin{tabular}{cccc}
\hline Nilai & Kategori & Frekuensi & Persentase (\%) \\
\hline $91-100$ & Sangat Tinggi & 0 & 0 \\
\hline $75-90$ & Tinggi & 7 & 25,93 \\
\hline $60-74$ & Sedang & 10 & 37,04 \\
\hline $40-59$ & Rendah & 5 & 18,52 \\
\hline $0-39$ & Sangat Rendah & 5 & 18,52 \\
\hline \multicolumn{7}{c}{ Jumlah } & 27 & 100 \\
\hline
\end{tabular}

Dari Tabel 1 terlihat bahwa dari 27 peserta didik yang mengikuti pretest, tidak ada peserta didik $(0,00 \%)$ berada pada kategori sangat tinggi, 7 peserta didik $(25,93 \%)$ berada pada kategori tinggi, 10 peserta didik $(37,04 \%)$ berada pada kategori sedang, 5 peserta didik (18,52\%) masingmasing berada pada kategori rendah dan sangat rendah. Oleh karena itu, hanya 7 peserta didik $(25,93 \%)$ dari 27 orang telah memperoleh nilai minimal 75. Jadi, tingkat kemampuan pemahaman konsep aljabar peserta didik berdasarkan hasil pretest dikatakan belum tuntas secara klasik dengan rata-rata kelas 57,56 dalam kategori rendah.

Tabel 2. Hasil Posttest Kemampuan Pemahaman Konsep Aljabar

\begin{tabular}{cccc}
\hline Nilai & Kategori & Frekuensi & Persentase (\%) \\
\hline $91-100$ & Sangat Tinggi & 2 & 7,41 \\
\hline $75-90$ & Tinggi & 19 & 70,37 \\
\hline $60-74$ & Sedang & 4 & 14,81 \\
\hline $40-59$ & Rendah & 2 & 7,41 \\
\hline $0-39$ & Sangat Rendah & 0 & 0,00 \\
\hline \multicolumn{7}{c}{ Jumlah } & 27 & 100 \\
\hline
\end{tabular}

Dari Tabel 2, terlihat bahwa dari 27 peserta didik yang mengikuti posttest, terdapat 2 peserta didik $(7,41 \%)$ berada pada katergori sangat tinggi, 19 peserta didik (70,37\%) berada pada kategori tinggi, 4 peserta didik $(14,81 \%)$ berada pada kategori sedang, 2 peserta didik $(7,41 \%)$ berada pada kategori rendah, dan tidak ada peserta didik (0,00\%) yang berada pada kategori sangat rendah. Oleh karena itu, 21 peserta didik $(77,78 \%)$ dari 27 orang telah memperoleh nilai minimal 75. Jadi, pembelajaran yang dilaksanakan dengan menggunakan LKPD berbasis masalah pokok bahasan bentuk aljabar dapat dikatakan tuntas secara klasik dan rata-rata kemampuan pemahaman konsep aljabar peserta didik meningkat menjadi 78,15 dengan kategori tinggi.

Pengembangan LKPD matematika berbasis masalah dalam penelitian ini menggunakan model pengembangan Plomp yang meliputi empat fase, yaitu: (a) fase investigasi awal (preliminary investigation), (b) fase desain (design), (c) fase realisasi (realization), and (d) fase tes, evaluasi, dan revisi 
(test, evaluation, and revision). Pada fase investigasi awal dilakukan analisis kebutuhan peserta didik, teori pendukung LKPD, analisis kurikulum, dan analisis materi ajar dengan cara mengumpulkan dan menganalisis informasi yang mendukung untuk merencanakan kegiatan selanjutnya. Pada fase ini diperoleh bahwa dalam proses pembelajaran matematika perlu didukung ketersediaan LKPD yang dapat meningkatkan kemampuan pemahaman konsep aljabar dan berakibat pada peningkatan hasil belajar matematika peserta didik. Pada fase desain dilakukan penyusunan kebutuhan LKPD dengan memperhatikan langkah-langkah model PBL, KI, dan KD serta indikator pencapaian kompetensi dan menentukan struktur LKPD, struktur LKPD secara umum yaitu sampul, kata pengantar, petunjuk penggunaan LKPD, daftar isi, halaman bab, peta konsep, langkah-langkah model PBL, dan subbab materi yang terdiri atas masalah, info, catatan, petunjuk, aktivitas, dan latihan soal. LKPD yang dikembangkan berbasis masalah pada pokok bahasan bentuk aljabar yang disesuaikan dengan tahapan model PBL. Fase realisasi dilakukan melalui penulisan LKPD dan pembuatan instrumen penelitian. Fase tes, evaluasi, dan revisi yang menunjukkan kualitas LKPD yang dikembangkan.

Berdasarkan rangkuman hasil validasi LKPD komponen isi, kebahasaan, penyajian dan kegrafikan menunjukkan bahwa LKPD yang dikembangkan telah memenuhi kriteria valid dengan nilai rata-rata validasi yaitu 3,2. Data kepraktisan menggunakan data keterlaksanaan LKPD, angket respon peserta didik dan angket respon guru. Hasil analisis data lembar keterlaksanaan LKPD diperoleh rata-rata 0,98 dengan kategori terlaksana sebagian. Hasil analisis data angket respon peserta didik dan guru berturut-turut yaitu 83,06 dan 75,83 dengan kategori respon positif.

Berdasarkan hasil analisis data lembar keterlaksanaan LKPD dan angket respon, hasil analisis data kepraktisan menunjukkan bahwa LKPD yang dikembangkan dikatakan praktis dalam penggunaannya. Hal ini sesuai dengan pendapat Tasdelen dan Koseoglu (2008) ${ }^{20}$ yang mengatakan bahwa respon positif peserta didik dan guru menunjukkan bahan ajar tersebut baik. Hal ini sejalan dengan pendapat Sari (2016) ${ }^{21}$ bahwa LKPD dengan kategori praktis mudah digunakan untuk memahami materi, waktu pembelajaran yang lebih efektif, dan dapat dijadikan sebagai buku pendamping.

Hasil analisis keefektifan diperoleh berdasarkan lembar pengamatan aktivitas peserta didik dengan rata-rata persentase 61,97 dengan kategori

${ }^{20}$ Ugur Tasdelen and Fitnat Koseoglu, "Learner-Friendly Textbooks: Chemistry Texts Based On a Contructivist View of Learning," Education Research Institute 9, no. 2 (2008): 136-147.

21 Ayu Ulan Sari, "Penngembangan Media Pembelajaran Berbantuan Web Dengan Pendekatan Etnomatika Pada Pokok Bahasan Bangun Ruang Sisi Datar" (Universitas Islam Negeri Raden Intan, 2016). 
baik, lembar pengamatan kemampuan guru mengelola pembelajaran dengan rata-rata seluruh aspek yaitu 4,14 dengan kategori baik, tingkat kemampuan pemahaman konsep aljabar peserta didik tuntas secara klasik dan rata-rata kemampuan pemahaman konsep aljabar peserta didik meningkat dari 57,56 dalam kategori rendah menjadi 78,15 dengan kategori tinggi. Berdasarkan hasil tersebut, hasil analisis keefektifan menunjukkan bahwa LKPD efektif dalam meningkatkan kemampuan pemahaman konsep matematika peserta didik. Hal ini sejalan dengan penelitian yang dilakukan oleh Hidayanti, As'ari dan Candra yang menyatakan bahwa LKS berbasis pemecahan masalah efektif dalam meningkatkan kemampuan peserta didik ${ }^{22}$. Selain itu, Yulia, Buyung, dan Relawati (2018) ${ }^{23}$ mengatakan bahwa LKS berbasis PBL menambah wawasan peserta didik dalam mempelajari matematika.

Berdasarkan hasil analisis data kevalidan, kepraktisan dan keefektifan dapat disimpulkan bahwa pengembangan Lembar Kerja Peserta didik (LKPD) berbasis masalah dapat meningkatkan pemahaman konsep aljabar peserta didik dengan kategori valid, praktis dan efektif. Perbedaan tampilan LKPD berbasis masalah dan LKPD di salah satu SMP Negeri di Kabupaten Soppeng terlihat pada Gambar 1.

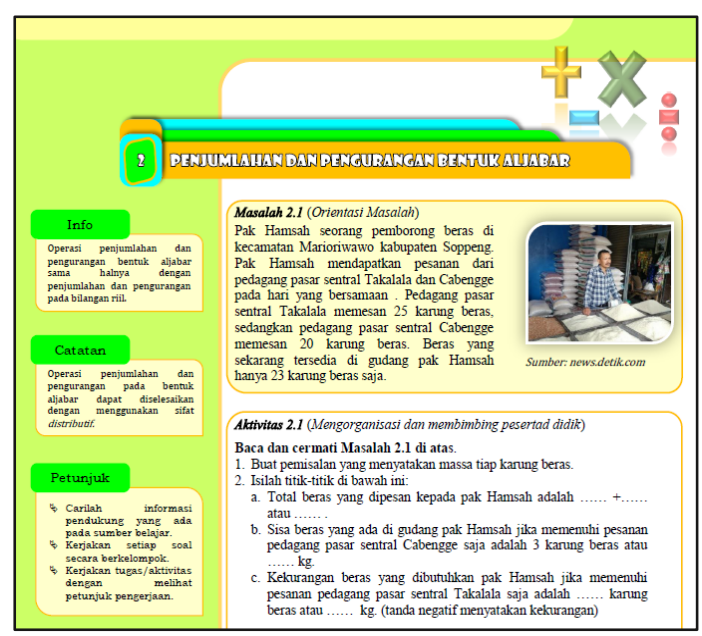

(a). LKPD Berbasis Masalah

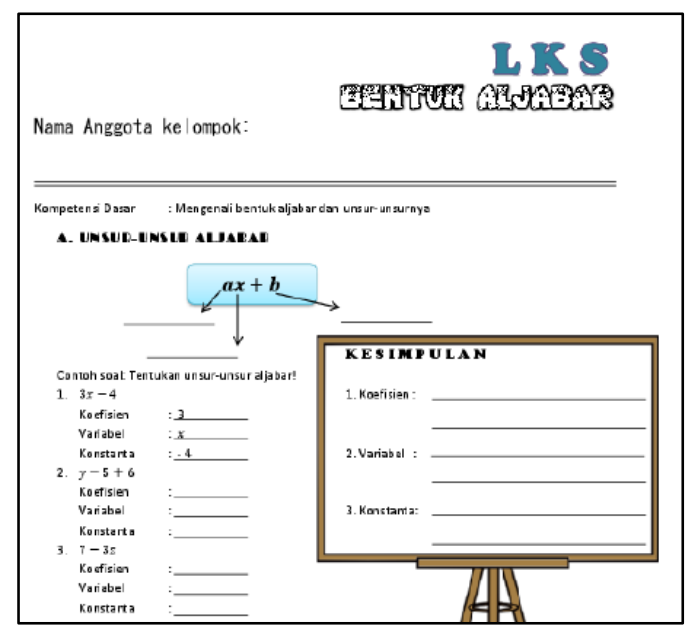

(b). LKPD di salah satu SMP Negeri di Kabupaten Soppeng

Gambar 1. Tampilan Perbedaan LKPD

22 Dwi Hidayanti, A. R. As'ari, and Tjang Daniel Candra, "Pengembangan Perangkat Pembelajaran Berbasis Pemecahan Masalah Untuk Meningkatkan Kemampuan Berpikir Kritis Peserta didik SMP Kelas IX," Jurnal Pendidikan: Teori, Penelitian, Dan Pengembangan 1, no. 4 (2016): 634-649.

${ }^{23}$ Sri Yulia, Buyung, and Relawati, "Pengembangan Lembar Kerja Peserta didik (LKS) Berbasis Problem Based Learning Pada Materi Bilangan Di Kelas VII SMP Negeri 22 Kota Jambi," Jurnal Pendidikan Matematika 2, no. 1 (2018): 61-70. 


\section{Kesimpulan}

Artikel ini telah menunjukkan proses pengembangan Lembar Kerja Peserta Didik (LKPD) berbasis masalah berdasarkan model Plomp yang meliputi 4 fase, yaitu: (a) fase investigasi awal, (b) fase desain, (c) fase realisasi, dan (d) fase tes, evaluasi, dan revisi. Hasil uji coba menyatakan LKPD memenuhi kriteria valid, efektif dan praktis. Hasil validasi LKPD berdasarkan kualitas isi, kualitas bahasa, kualitas penyajian, dan kualitas kegrafikaan berada pada kategori valid dengan nilai rata-rata 3,2. LKPD dinyatakan praktis dengan rata-rata untuk seluruh aspek pengamatan keterlaksanaan LKPD sebesar 0,98 dengan kategori terlaksana sebagian, ratarata persentase angket respon peserta didik dan guru berturut-turut 83,06 dan 75.83 dengan kategori respon positif. LKPD dinyatakan efektif dengan rata-rata persentase aktivitas peserta didik untuk keseluruhan pertemuan pembelajaran adalah 61,97\% berada dalam kategori aktivitas belajar baik, rata-rata seluruh aspek aktivitas guru sebesar 4,14 dengan kategori baik, tingkat kemampuan pemahaman konsep aljabar peserta didik tuntas secara klasik dan rata-rata kemampuan pemahaman konsep aljabar peserta didik meningkat dari 57,56 dalam kategori rendah menjadi 78,15 dengan kategori tinggi. Berdasarkan hasil analisis data kevalidan, kepraktisan dan keefektifan maka dapat disimpulkan bahwa pengembangan Lembar Kerja Peserta didik (LKPD) berbasis masalah dapat meningkatkan pemahaman konsep aljabar peserta didik dengan kategori valid, praktis dan efektif.

\section{Daftar Pustaka}

Afrida, Juniar, Adlim, dan A. Halim. "Pengembangan Lembar Kerja Peserta didik (LKS) Berbasis Inkuiri Terbimbing Untuk Meningkatkan Kemampuan Keterampilan Proses Sains Dan Minat Peserta didik Pada Pembelajaran Fluida Statis Di SMA Negeri 11 Banda Aceh." Jurnal Pendidikan Sains Indonesia 3, no. 1 (2015): 93-106.

Aji, Sudi Dul, dan Muhammad Nur Hudha. "Karya Ilmiah Peserta didik SMP Dan SMA Melalui Authentuc Problem Based Learning (APBL)." Jurnal Inspirasi Pendidikan 6, no. 1 (2016): 835-841.

Hidayanti, Dwi, As'ari, A. R., dan Tjang Daniel Candra. "Pengembangan Perangkat Pembelajaran Berbasis Pemecahan Masalah Untuk Meningkatkan Kemampuan Berpikir Kritis Peserta didik SMP Kelas IX." Jurnal Pendidikan: Teori, Penelitian, Dan Pengembangan 1, no. 4 (2016): 634-49.

Nidyasafitri, Farah, Vina Serevina, dan Cecep E. Rustana. "Pengembangan LKS Berbasis PBL (Problem Based Learning) Pad Pokok Bahasan Momentum Dan Impuls Fisika SMA Kelas XI." Jurnal Wahana Pendidikan Fisika, 2017, 51-57.

Nurhadi. Pembelajaran Kontekstual Dan Penerapannya Dalam KBK. Malang: UM Press, 2014. 
Nurhayati, Fitri, Joko Widodo, dan Etty Soesilowati. "Pengembangan LKS Berbasis Problem Based Learning (PBL) Pokok Bahasan Tahap Pencatatan Akuntansi Perusahaan Jasa." JEE: Journal of Economic Education 1 (2015): 14-19.

Pusparini, Novi. "Efektivitas Model Pembelajaran Kooperatif Tipe TGT Terhadap Prestasi Belajar Matematika Peserta didik SMP Kelas VIII." UIN Sunan Kalijaga, 2011.

Qomario, dan Putri Agung. "Pengembangan Lembar Kerja Peserta didik (LKS) IPA Berbasis ICT Sebagai Media Pembelajaran." Jurnal Pendidikan Dan Pembelajaran Dasar 5, no. 2 (2018): 239-246.

Richard I., Arends. Learning to Teach. Seventh Ed. New York: McGraw-Hill, 2008.

Risfalidah, Rosidin, Undang dan Sutiarso, "Pengembangan LKPd Berbasis Problem Based Learning ditinjau dari disposisi dan Kemampuan Komunikasi Matematis", JPPM12, No. 2 (2019).

Rochmad. "Desain Model Pengembangan Perangkat Pembelajaran Matematika." Jurnal Kreano 3, no. 1 (2012).

Rosliana, Ina, "Pengembangan LKPD Matematika dengan Model Learning Cycle Berbantuan Mind Mapping", Jurnal Pengembangan Pembelajaran Matematika (JPPM) 1, no. 1 (2019).

Safriadi. "Pengembangan Lembar Kerja Peserta didik Berbasis Think-ThalkWrite Pada Mata Pelajaran Matematika Kelas XI SMA Negeri 11 Makassar." UIN Alauddin Makassar, 2015.

Sari, Ayu Ulan. "Pengembangan Media Pembelajaran Berbantuan Web Dengan Pendekatan Etnomatika Pada Pokok Bahasan Bangun Ruang Sisi Datar." Universitas Islam Negeri Raden Intan, 2016.

Savery. "Over of Problem-Based Learning: Definitions and Distinctions." Interdiciplinari Journal 1, no. 1 (2006): 9-20.

Setyanto, Heri, Sudarmin, dan Novi Ratna Dewi. "Pengembangan LKS IPA Berbasis Problem Based Learning Pada Tema Pencemaran Lingkungan Guna Menumbuhkan Kemandirian Peserta didik." UNNES Science Education Journal 4, no. 3 (2015): 990-997.

Sumaryanta. Bahan Perkuliahan Telaah Kurikulum Pendidikan Matematika. Yogyakarta: UIN Sunan Kalijaga, 2009.

Tasdelen, Ugur, dan Fitnat Koseoglu. "Learner-Friendly Textbooks: Chemistry Texts Based On a Contructivist View of Learning." Education Research Institute 9, no. 2 (2008): 136-147.

Trnova, Eva, dan Josef Trna. "Implementation of Creativity in Science Teacher Training." International Journal on New Trends in Education and Their Implications 5, no. 3 (2014): 54-63.

Yulia, Sri, Buyung, dan Relawati. "Pengembangan Lembar Kerja Peserta didik (LKS) Berbasis Problem Based Learning Pada Materi Bilangan Di Kelas VII SMP Negeri 22 Kota Jambi." Jurnal Pendidikan Matematika 2, no. 1 (2018): 61-70.

Zulfikar, A. 'Analyzing Educational Univeristy Students' Conceptions Through Smartphone-Based PDEODE Tasks on Magnetic Field in Sveral Mediums." In In AIP Conference Proceedings. AIP Publishing, 2017. 